\title{
Örtü Altı Domates Yetiştiriciliğinde Domates Güvesi (Tuta absoluta Meyrick)'ne Karşı Kullanılan Feromon ve Ferolite Tuzaklarının Etkinliğinin Karşılaştırııması
}

\author{
Zuhal ÖZKAN ${ }^{1 *}$ Levent ÜNLÜ² Ekrem ÖGÜR² \\ ${ }^{1}$ Gaziantep Üniversitesi Araban Meslek Yüksekokulu, Bitkisel ve Hayvansal Üretim Bölümü, GAZiANTEP \\ [ORCID: http://orcid.org/0000-0002-7195-3461] \\ ${ }^{2}$ Selçuk Üniversitesi Ziraat Fakültesi Bitki Koruma Bölümü, KONYA \\ [ORCID: http://orcid.org/0000-0002-3142-3756 (L. Ünlü), 0000-0002-8242-2754 (E. ÖGÜR)] \\ * Sorumlu yazar: zuhalozkan@gantep.edu.tr
}

Öz

Bu çalışma, 2011-2012 sera üretim mevsiminde Çumra (Konya) ilçesinde bulunan seralarda Domates Güvesi [Tuta absoluta (Meyrick, 1917)]'nin mücadelesinde kullanılan feromon ve Ferolite tuzaklarının etkinliğini tespit etmek amacıyla yürütülmüştür. İki adet beşer da seralara (1 ve 2 nolu sera) ikişer adet delta tipi eşey feromon tuzakları ve birer adet Ferolite ismi verilen hem ışık hem de eşey feromon tuzağı kombinasyonu olarak kullanılan tuzaklarla, zararlının kitle halinde yakalanıp, tuzakların etkinliği karşılaştııılmıştır. Haftalık yapılan kontrollerde tuzaklardaki yakalanan ergin bireyler kaydedilerek, popülasyon gelişimi saptanmıştır. Bir ve 2 nolu seralarda eşey feromon tuzaklarında yakalanan ortalama ergin sayısı en fazla sırasıyla 640 ve 626 adet/hafta, Ferolite tuzaklarında yakalanan ergin sayısı ise sırasıyla 1250 ve 1525 adet/hafta olarak tespit edilmiştir. Tuzakların etkililiğini araştırmak için yapılan $t$ testi sonucunda, 1 ve 2 nolu seralardaki feromon ve Ferolite tuzaklarında yakalanan ergin sayılarının $t$ değeri sırasıyla -2.02 ve -2.15 bulunduğu, aralarındaki farkın istatistiki olarak önemli olduğu tespit edilmiştir $(P<0.05)$. Ferolite tuzaklarındaki ergin birey sayısının, eşey feromon tuzaklarındaki ergin birey sayısından iki kat fazla olduğu bulunmuştur. Sonuç olarak, Ferolite tuzaklarına, hem erkek hem de dişi bireyler gelmesinden dolayı feromon tuzaklarına göre daha etkili oldukları saptanmıştır. Tuta absoluta'nın mücadelesinde Ferolite tuzakların kitle yakalama tekniği için başarıyla kullanılabileceği, eşey feromonlarıyla popülasyonunun belirlenip azaltılabileceği ve böylelikle bulaşıklık oranının, ergin sayıları azaltılarak düşürülebileceği kanısına varılmıştır.

Anahtar Kelimeler: Domates, Domates güvesi, Ferolite, Feromon, Konya,

\section{Comparison of the Efficiency of Pheromone and Pherolite Traps Used Against Tomato Moth (Tuta absoluta Meyrick) in Greenhouse Tomato Growing}

\begin{abstract}
This study was conducted to determine the efficiency of pheromone and Ferolite traps against tomato moth [Tuta absoluta (Meyrick, 1917)] in greenhouses in Çumra (Konya) district during greenhouse growing season in 2011 and 2012. In two 5 da greenhouses (number 1 and 2), the effectiveness of the traps were compared by locating and mass trapping with two delta type pheromone traps and one Ferolite trap, which is combination of both light and pheromone traps, for each greenhouse. Captured adults were recorded weekly and the population development was determined. The highest average number of adults caught in pheromone traps were 640 and 626 adult/week, in Ferolite traps were 1250 and 1525 in greenhouses 1 and 2, respectively, As a result of the $t$ test to investigate the effectiveness of the traps, the $t$ values of the adult numbers which were caught in pheromon and Ferolite traps in greenhouse 1 and 2 were -2.02 and -2.15 , respectively and the differences between them are statistically significant $(P<0.05)$. It was found that the number of adult in Ferolite traps was twice as
\end{abstract}


many as the number of adult in pheromone traps. Consequently, the Ferolite traps were determined more effective than the pheromone traps due to trapping both male and female adults. We concluded that Ferolite traps could be used successfully for mass trapping against $T$. absoluta, the population could be determined and reduced by pheromone traps, and thus the infestation ratio could be reduced by decreasing the adult numbers.

Key Words: Tomato, Tomato moth, Ferolite, Pheromone, Konya,

\section{Giriş}

Teknolojinin ilerlemesi ve serada yapılan yetiştiricilik sonucu her mevsim üretilen, tüketilen ve ticareti yapılan sebzelerden biri olan domates, çiftçilerin önemli gelir kaynaklarından birini oluşturmaktadır. İçinde A, B1, B2, C, K vitaminleri, niacin, protein, yağ, karbonhidrat, potasyum, kalsiyum ve demir bulunmaktadır. Taze olarak yenildiği gibi salça, domates suyu, konserve turşu, reçel, ketçap şeklinde de tüketilmektedir (Anonim, 2016a).

Dünyada toplam 4.8 milyon ha alanda 163.9 milyon ton domates üretimi yapılmaktadır. Domates üretiminde dünyada önde gelen ülkeler sırası ile Çin Halk Cumhuriyeti (50 milyon ton), Hindistan (17.5 milyon ton), ABD (13.2 milyon ton), Türkiye (11.8 milyon ton) iken hektara göre verimin en yüksek olduğu ülke Hollanda'dır. Çin Halk Cumhuriyeti dünya üretiminin yaklaşık üçte birini tek başına gerçekleştirmekte olup, ülkemizin küresel domates üretiminden aldığı pay \%7.2 seviyesindedir (Anonim, 2016b). Konya ilinde 2015 yılı verilerine göre, 37.800 da alanda 177.998 ton sofralık domates üretimi yapılmıştır. Konya'nın ilçelerinden biri olan Çumra'da domates üretiminde önemli bir yere sahip olup
3.056 da alanda 14.997 tonluk üretim yapılmaktadır (Anonim, 2016c).

Domates yetiştiriciliğini olumsuz yönde etkileyen, kalite ve verim kayıplarına neden olan pek çok zararlı ve hastalık bulunmaktadır. Bu zararlılardan birisi olan Domates Güvesi Tuta absoluta (Meyrick) domates bitkisinin tüm organlarında beslenebildiği gibi önlem alınmadığı sürece \%100'e varan oranda ürün kaybına neden olabilmektedir (Anonim, 2016d ) Tuta absoluta larvası domates bitkisinin kök hariç tüm kısımlarında (meyve, sap ve gövde) ve tüm fenolojik dönemlerinde (fide, vejetatif büyüme, çiçeklenme, meyve gelişimi ve hasat) zarar yapabilmektedir. Larva domates yapraklarında iki epidermis arasına girerek galeriler açmakta ve beslenmesine devam etmektedir. Larvanın yaprakta açtığı galeriler daha sonra kahverengine dönüşerek bitkinin tamamen kurumasına sebep olabilmektedir. Zararlının meyvede açtığı galerilere sekonder mikroorganizmaların da yerleşmesiyle çürümeler meydana gelmekte, meyvenin pazar değeri oldukça düşmektedir. Zararlı yoğun popülasyonlarda ve kurak koşullarda domateste \%50-100 oranında ürün kayıplarına yol açabilmektedir (EPPO, 2005). 
Zararlı ilk kez 1917 yılında Peru'da görülmüş ve zamanla Güney Amerika'nın tamamına yayılmıştır (Barrientos ve ark., 1998; Estay, 2000). Domates güvesi, $T$. absoluta 1900'lü yılların başlarında sadece Güney Amerika'da bulunmasına rağmen, ülkeler hatta kıtalar arasındaki ithalat/ihracat nedeniyle Avrupa ve Asya ülkelerine de 2000'li yıllarda bulaşmıştır (Cáceres, 1992). Domates bitkisinin önemli bir zararlısı olan T. absoluta, 2009 yılında ülkemizde ilk kez zarar yapmaya başlamıştır. Ülkemizde varlığı ilk defa Kılıç (2010) tarafından İzmir iline bağlı Urla ilçesinde, daha sonra da Antalya'daki seralarda (Erler ve ark., 2010), Mersin'de (Karut ve ark., 2011), Konya ilinde domates ve patates (Ünlü, 2011; 2012) bitkilerinde zararlının varlığı tespit edilmiştir. Güneydoğu Anadolu Bölgesi'nde domates yetiştiriciliğinin en fazla yapıldığı Şanlıurfa, Diyarbakır ve Mardin illerinde 2011-2012 yıllarında açık alanda zararlının yayılışı, bulaşıklık durumu tespit edilmiş, doğal düşmanları araştırılarak zararının mücadelesine yönelik çalışmalar yürütmüştür. (Bayram ve ark., 2014a, b)

Dünyada ve ülkemizde $T$. absoluta'nın alternatif konukçularının sayıca fazla olması, çok döl vermesi, zararlıya karşı ruhsatlı kimyasalların bulunmaması bu zararlıya karşı nasıl bir mücadele yapılacağının bilinememesi gibi sebeplerden dolayı domates üretiminde ekonomik kayıpların oluşmasına neden olmuştur.

Konya ili Çumra ilçesinde yürütülen bu çalışmada, domateste ciddi kayıplara yol açan T. absoluta 'ya karşı örtüaltı alanlarında feromon ve Ferolite tuzaklarını kullanarak tuzakların etkinliği belirlenmiştir. Çalışmadan elde edilen haftalık ergin sayıları doğrultusunda tuzakların zararlı mücadelesindeki kullanımı ile ilaçlama sayısında azalma sağlanması amaçlanmıştır.

\section{Materyal ve Metot}

\section{Materyal}

Çalışma 2011-2012 üretim sezonu boyunca Konya ilinin Çumra ilçesinde bulunan Konya Şeker A.Ş. Çumra Şeker Fabrikası'na ait iki adet beş da büyüklüğündeki cam ve polikarbon yapıdaki seralarda yürütülmüştür. Her iki serada topraksı kültür olarak kaya yününe yaklaşı 12.000 adet domates fidesi yetiştirilmiştir. Çalışmanın ana materyalini domates yetiştiriciliği yapılan her alanda bitkilerde zarar yapan Domates Güvesi (Tuta absoluta), Russel IPM firmasından temin edilen $0.5 \mathrm{mg}$ E3,Z8,Z11-Tetradecatrienyl acetate feromon, zararlının ergin popülasyon gelişiminin saptanmasında kullanılan eşey feromon tuzakları ve kitle halinde yakalama tekniği için kullanılan ışık + feromon tuzağı kombinasyonu olan "Ferolite" isimli tuzaklar oluşturmuştur.

\section{Metot}

Çumra'daki iki adet beşer dekarlık seralarda, ikişer adet delta tipi eşey feromon tuzakları (Şekil 1) ve birer adet Ferolite ismi verilen hem Işık hem de eşey feromon tuzağı kombinasyonu olarak kullanılan tuzaklardan (Şekil 2) faydalanarak tuzakların etkinliği 
araştırılmıştır. Eşey feromon tuzaklar arası mesafe $40 \mathrm{~m}$ olup Ferolite tuzağı eşey feromon tuzaklarının ortasında ve her iki eşey feromon tuzağına $20 \mathrm{~m}$ uzaklıktadır. Bu tuzaklar haftalık olarak kontrol edilmiş ve tuzaklara gelen erginler sayılarak kaydedilmiştir. Ferolite tuzakların eksilen suları her hafta tamamlanmıştır. Ferolite tuzakları ile feromon tuzakları arasında istatistiki farkın olup olmadığı $t$ testi kullanılarak ortaya çıkarılmıştır.

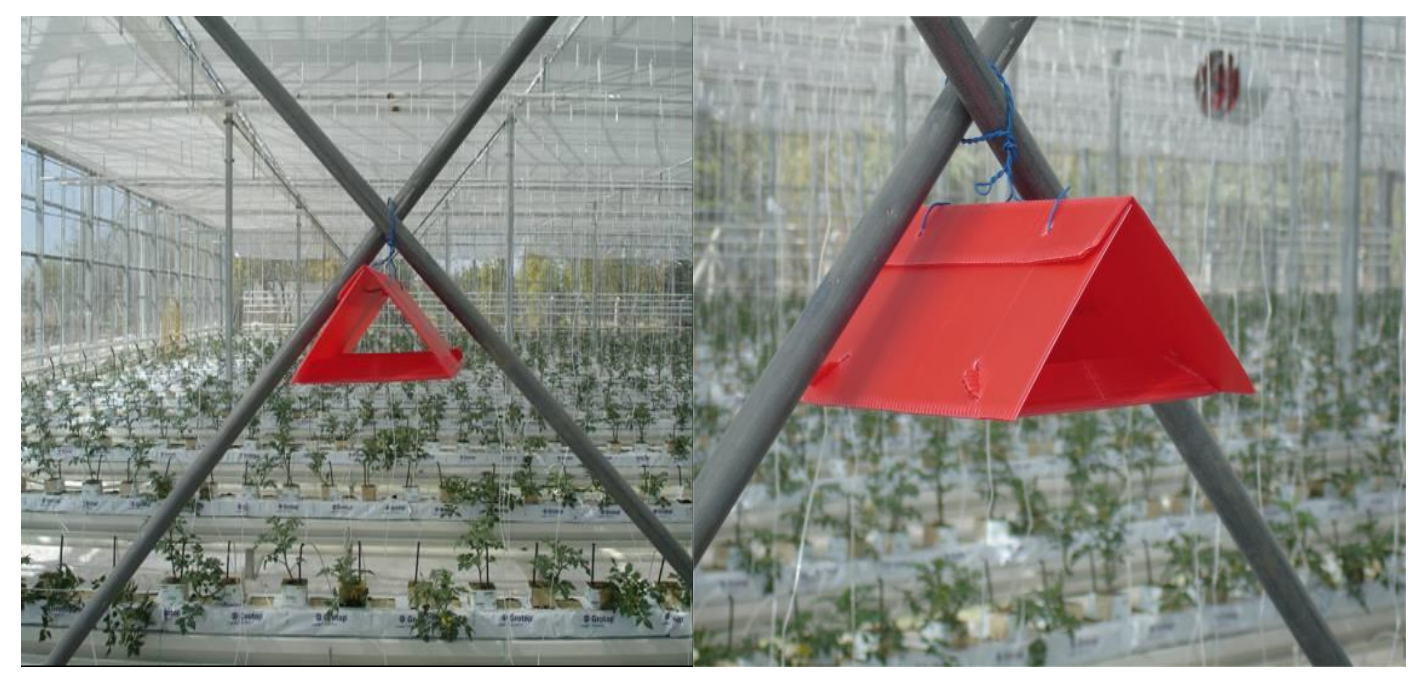

Şekil 1. Çalışmada kullanılan feromon tuzakları

Figure 1. The pheromone traps used in the study

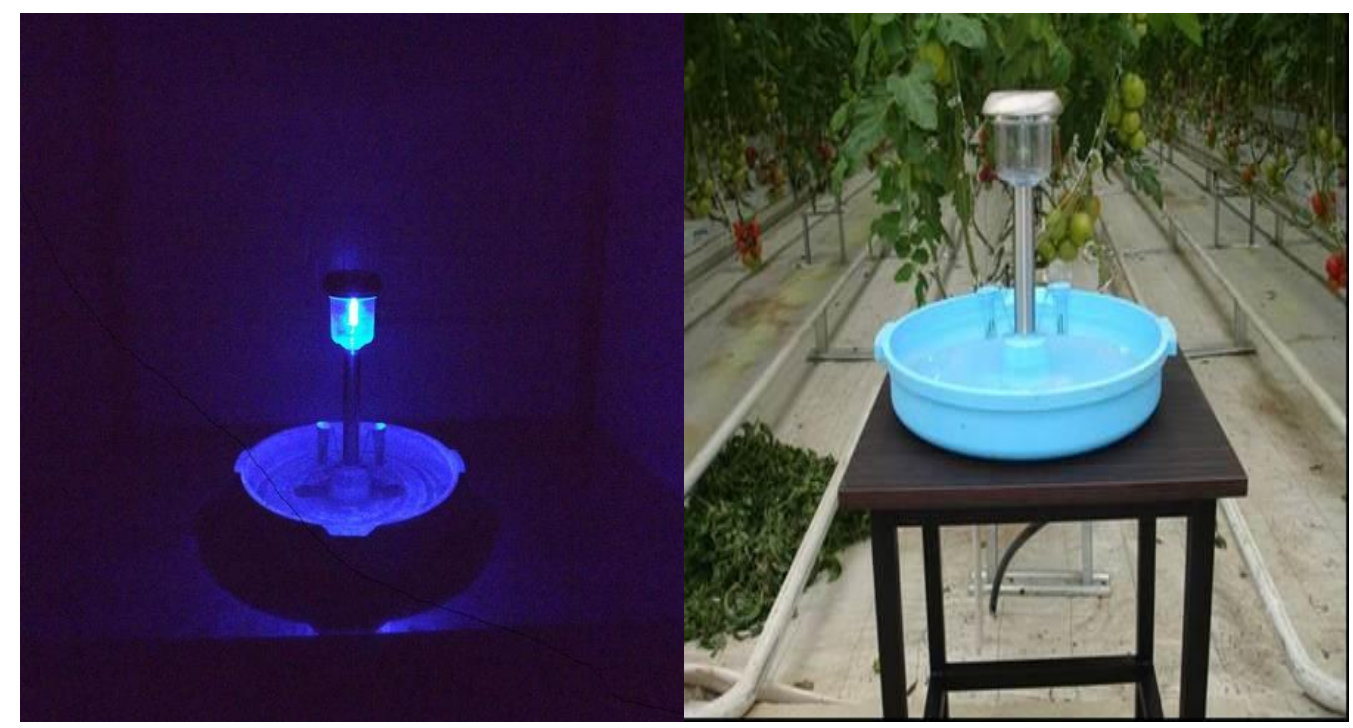

Şekil 2. Çalışmada kullanılan Ferolite tuzakları

Figure 2. The Ferolite traps used in the study

\section{Araştırma Bulguları ve Tartışma}

Konya ilinin Çumra ilçesinde bulunan Çumra Şeker Fabrikası'na ait iki serada,
2011 yılı Ekim ayından, 2012 yılı Temmuz ayına kadar olan 10 aylık üretim sezonu içerisinde tuzaklardaki haftalık $T$. absoluta ergin popülasyon takibi ve tuzakların etkinliğini kıyaslamak için iki 
adet delta tipi eşey feromon tuzağı kurulmuştur. Bu verilerden 1 nolu seraya asılmış, birer tane de Ferolite tuzağı ait olanlar Şekil 1'de verilmiştir.

1 Nolu Sera

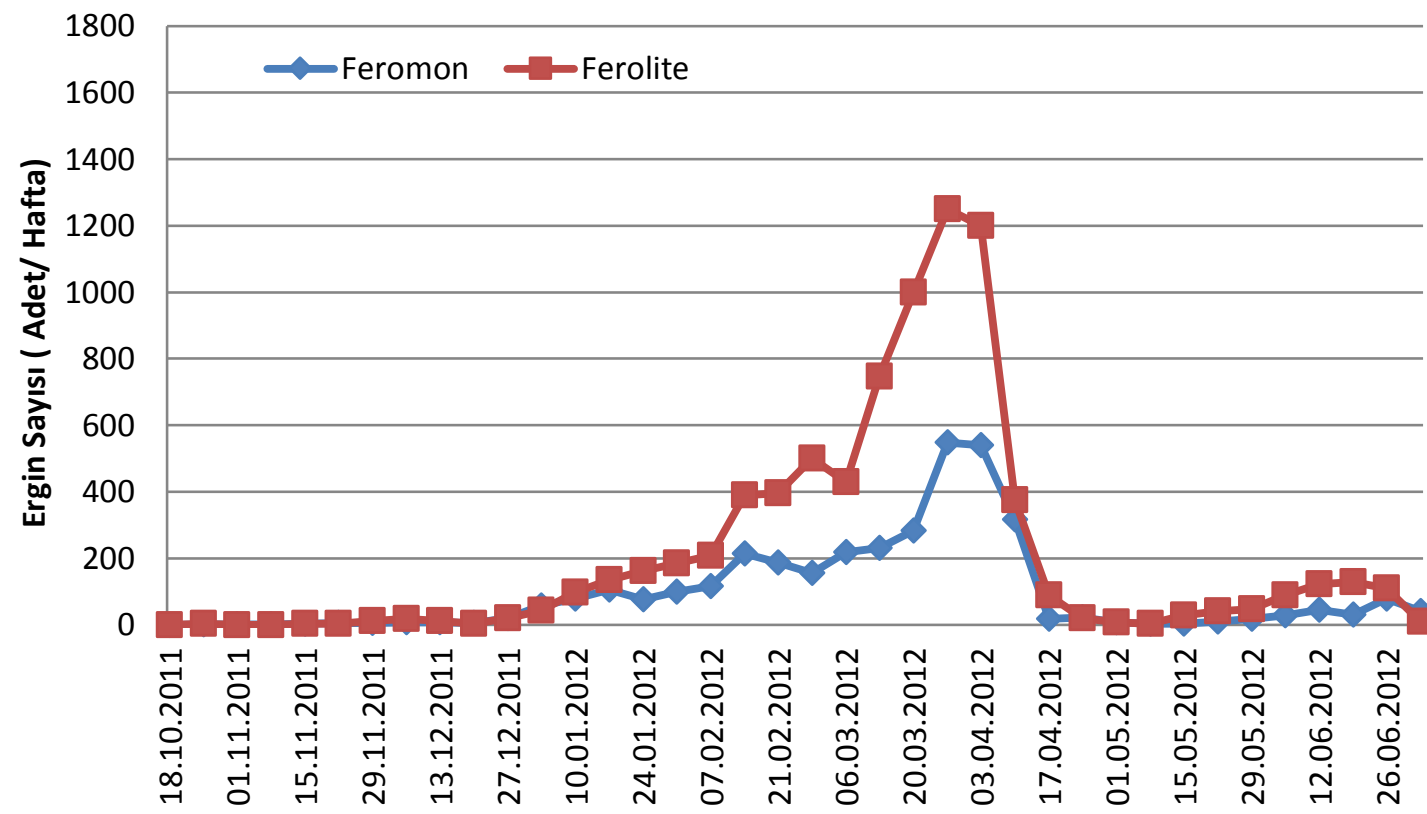

Şekil 3. Domates Güvesi'nin 1 nolu serada bulunan feromon ve Ferolite tuzaklarındaki ergin sayısı

Figure 3. The number of adult of tomato moth in the pheromone and Ferolite traps found in greeenhouse number 1

T. absoluta erginleri 1 nolu serada bulunan feromon ve Ferolite tuzaklarında 25 Ekim 2011 tarihinde yakalanmaya başlanmıştır. $\mathrm{Bu}$ tarihte feromon tuzağında 1 adet/hafta ergin yakalanırken Ferolite tuzağında 4 adet/hafta ergin bulunmuştur. 27 Aralık 2011 tarihinde tuzaklarda yakalanan ergin sayıları ile tuzaklar arasında belirli bir farkın oluştuğu gözlemlenmiştir. Bundan sonraki haftalarda tuzaklardaki ergin sayısı giderek artmaya başlamıştır. Tuzaklardaki ergin sayısı 20 Aralık 2011 tarihine kadar düşük seviyede (4.5-15 adet/hafta) gerçekleşirken, Aralık ayının son haftasında (27 Aralık 2011) artmaya (21-40 adet/hafta) başlamıştır. Feromon ve Ferolite tuzaklarındaki ergin sayısının
17 Ocak 2012 tarihinde arttığı saptanmıştır. $\mathrm{Bu}$ tarihte feromon tuzaklarında yakalanan ergin sayısı 105 adet/hafta, Ferolite tuzağında ise 135 adet/hafta olarak bulunmuştur. Bu tarihten sonra 14 Şubat 2012 tarihinde feromon tuzağında 214 adet/hafta, Ferolite tuzağında 389 adet/hafta ergin tespit edilmiştir. Mart ayı sonunda (27 Mart 2012) popülasyon en yüksek tepe noktalarına feromon tuzağında 548 adet/hafta, Ferolite tuzağında 1250 adet/hafta erginle ulaşmıştır. Mart ayının sonundan itibaren tuzaklarda yakalanan ergin sayısında azalma saptanmıştır. Sezon sonuna doğru olan popülasyon artışı ile ergin sayısı 
Çizelge 1. Konya ili Çumra ilçesinde 1 nolu serada yapılan ergin sayımı sonucu feromon ve Ferolite tuzakları etki düzeyi

Table 1. The effect level of feromon and Ferolite traps resulted from adult counting performed in greenhouse number 1 in Çumra province of Konya

\begin{tabular}{|c|c|c|c|c|c|c|}
\hline Uygulama Alanı & Özellikler & T testi & Min. & Max. & Ortalama $\pm \mathrm{SH}$ & $P$ \\
\hline & Feromon & & 0.0 & 548.0 & $94.4 \pm 22.3^{b^{*}}$ & \\
\hline \multirow[t]{2}{*}{ 1. Sera } & & -2.02 & & & & 0.05 \\
\hline & Ferolite & & 0.0 & 1250.0 & $207.6 \pm 53.4^{a}$ & \\
\hline
\end{tabular}

${ }^{*}$ Aynı sütunda farklı harflerle gösterilen ortalamalar arasında istatistiki fark vardır $(\mathrm{P}<0.05)$.

Araştırmanın yürütüldüğü bir diğer ve Ferolite tuzaklarındaki ergin sayısı ise sera olan 2 nolu serada bulunan feromon Şekil 4'te verilmiştir.

2 Nolu Sera

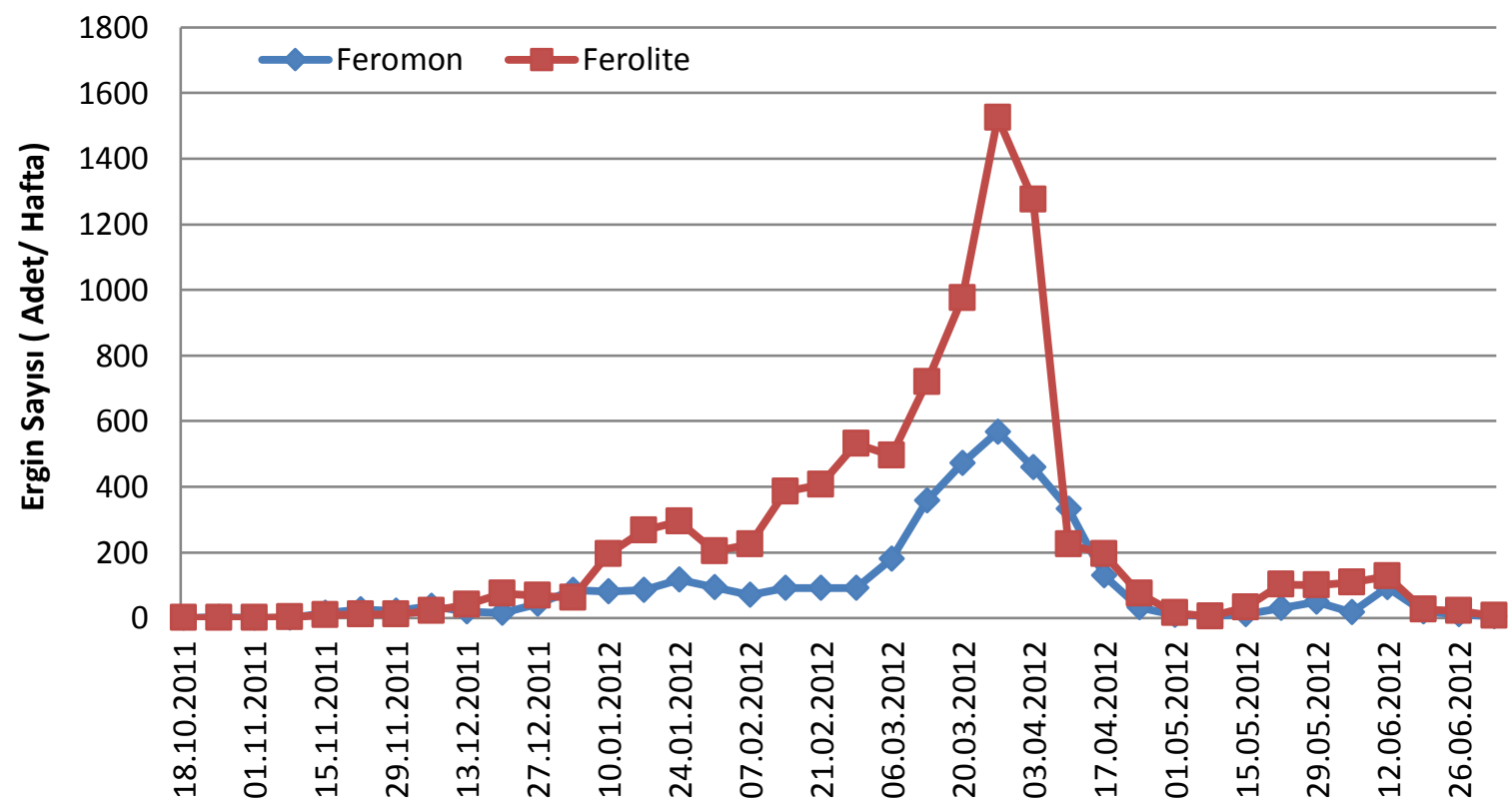

Şekil 4. Domates Güvesi'nin 2 nolu serada bulunan feromon ve Ferolite tuzaklarındaki ergin sayısı Figure 4. The number of adult of tomato moth in the pheromone and Ferolite traps found in greeenhouse number 2

12 Haziran tarihinde tekrar bir artışla feromon tuzağında 45 adet/hafta, Ferolite tuzağında ise 122 adet/hafta gözlenmiştir. Haziran ayının ortalarından itibaren tuzaklarda yakalanan ergin sayısı düşmeye başlamıştır. Domates üretimi sezon boyunca serada yaklaşık 4-5 tepe noktası meydana geldiği tespit edilmiştir (Şekil 3). 1 nolu serada kullanılan feromon ve Ferolite tuzaklarında yapılan haftalık ergin sayımına göre tuzaklar arası etkinlik farkının istatistiki olarak önemli olduğu tespit edilmiştir $(P<0.05)$ (Çizelge 1).

Tuta absoluta erginleri 2 nolu serada bulunan tuzaklarda, 25 Ekim 2011 tarihinden itibaren yakalanmaya başlamıştır. Feromon tuzaklarında 08 
Kasım 2011 tarihine kadar ergin 1525 adet/hafta seviyelerine ulaşmıştır. bulunmayıp, Ferolite tuzağında 2 Mevsim boyunca artış ve azalış gösteren adet/hafta ergin tespit edilmiştir. ergin sayısı tuzaklardaki en yüksek Tuzaklarda ergin sayısı 15 Kasım 2011 değerlerine 27 Mart 2012 tarihinde tarihinden itibaren artmaya (15-10 feromon tuzağında 568 adet/hafta, adet/hafta) başlamıştır. Ergin sayısının Ferolite tuzağında ise 1525 adet/hafta artmasıyla 06 Aralık 2011 tarihinde tespit edilmiştir. Bu tarihten sonra hızlı feromon tuzağında 36, Ferolite tuzağında bir azalış periyoduna giren erginler, 21 adet/hafta ergin ile ilk tepe noktası oluşmuş, 03 Ocak 2012 tarihinde ilk oluşan tepe noktasındaki ergin sayısından daha fazla bir popülasyon ile ikinci tepe noktası feromon tuzağında 85 adet/hafta Ferolite tuzağında 61adet/hafta ergin ile yakalanmıştır. Mevsim boyunca artış ve azalış gösteren ergin sayısı 27 Mart 2012 tarihinde serada bulunan feromon tuzağındaki ergin sayısı en yüksek değere 568 adet/hafta iken Ferolite tuzağında ise domates üretim sezonu ortalarında tuzaklardaki ergin artışı kadar olmasa da 29 Mayıs ile 12 Haziran tarihlerinde son kez tepe noktası (49-93 adet/hafta) oluşturmuştur. Bu tarihlerde Ferolite tuzağında (100-127 adet/hafta) ergin bulunmuştur (Şekil 4). 2 nolu serada kullanılan feromon ve Ferolite tuzaklarında yapılan haftalık ergin sayımı sonucuna göre tuzaklar arası etkinlik farkının istatistiki olarak önemli olduğu tespit edilmiştir $(P<0.05)$ (Çizelge 2$)$

Çizelge 2. Konya ili Çumra ilçesinde 2 nolu serada yapılan ergin sayımı sonucu feromon ve Ferolite tuzakları etki düzeyi

Table 2. The effect level of feromon and Ferolite traps resulted from adult counting performed in greenhouse number 2 in Çumra province of Konya

\begin{tabular}{lcccccc}
\hline Uygulama Alanı & Özellikler & T testi & Min. & Max. & Ortalama \pm SH & $P$ \\
\cline { 3 - 5 } & Feromon & & 0.0 & 568.0 & $99.1 \pm 23.3^{\mathrm{b}}$ & \\
2. Sera & & -2.15 & & & & 0.03 \\
& Ferolite & & 0.0 & 1525.0 & $232.5 \pm 57.5^{\mathrm{a}}$ & \\
\hline
\end{tabular}

${ }^{*}$ Aynı sütunda farklı harflerle gösterilen ortalamalar arasında istatistiki fark vardır $(\mathrm{P}<0.05)$.

Çalışmada feromon ve Ferolite tuzakları arasında tuzakların etkililiğini araştırmak için yapılan $t$ testi sonucunda, 1 ve 2 nolu seralardaki tuzaklarda yakalanan ergin sayılarının $t$ değeri sırasıyla -2.019 ve -2.149 bulunduğu, aralarındaki farkın istatistiki olarak önemli olduğu tespit edilmiştir $(P<0.05)$. Buna göre, Ferolite tuzaklarının, feromon tuzaklarına göre erginleri yakalamada daha etkili oldukları saptanmıştır.

Domates güvesi, çok kısa süre içerisinde ülkemizde yetiştiriciliği yapılan tüm bölgelerde yayılarak, domates bitkisinde önemli ve ekonomik zararlar oluşturmuştur. Filho ve ark. (2000), tarla denemelerinde feromon tuzaklarında üst üste üç gecede tuzak başına 869 adet, Ferrara ve ark. (2001) ise normal 
feromon dozunda 201 adet erkek birey yakalanıldığını, yüksek feromon dozu uygulandığında yakalanan ergin sayısının 1200 adet olduğunu bildirmişlerdir. Uşak'ta bulunan sera ve açık alanlarda yürütülen çalışma sonucunda, zararlının tuzaklarda yakalanan ergin sayısı seralarda en fazla 483 adet/hafta, açık alanlarda 351 adet/hafta olarak belirlemişlerdir (Aksoy ve Karaca, 2015). Portakaldalı ve ark. (2013) Adana' da açık alanda bu sayıyı tuzak başına en fazla 869 ergin olarak tespit etmişlerdir. Şanlıurfa'da açık alanlarda yapılan çalışmalarda tuzaklarda en fazla yakalanan birey sayısı 2010 yılında 370 adet/tuzak, 2011 yılında ise 978 adet/tuzak olmuştur (Mamay ve Yanık, 2012). Bu çalışmada tuzakların kurulduğu 1 ve 2 nolu seralarda feromon tuzağında yakalanan ortalama ergin sayısı en fazla sırasıyla 640 ve 626 adet/hafta olarak bulunmuştur. Ferolite tuzaklarında yakalanan ergin sayısı ise sırasıyla 1250 ve 1525 adet/hafta olarak tespit edilmiştir. Ülkemizde yapılan çalışmalara bakıldığında domates üretimi yapılan örtü altı ve açık alanlarda kullanılan feromon tuzaklarında yakalanan ergin sayısı en fazla Adana'da açık alanlarda 869 adet/hafta iken kullanmış olduğumuz Ferolite tuzağında ise ergin sayısı en fazla 1525 adet/hafta yakalanarak feromon tuzaklarına göre daha etkili olduğu görülmektedir.

\section{Sonuçlar}

Çalışmanın yürütüldüğü seralarda bulunan feromon ve Ferolite tuzaklarındaki T.absoluta ergini sayısı 2 nolu serada, 1 nolu seraya göre ergin sayısının daha yüksek olduğu bulunmuştur. Bu durumun nedeninin, seralar arası yapı malzemesi farklılığından kaynaklanabileceği düşünülmektedir. 1 nolu sera cam malzemeden, 2 nolu sera plastik (polikarbon) malzemeden yapılmış olması ve plastik seranın cam seraya göre iklim koşullarından daha fazla etkilenmesinin, ISı geçirgenliğinin fazla olmasından kaynaklanabileceği düşünülmektedir. Yaklaşık dört haftada bir tepe noktası oluşturarak ergin sayısındaki artış-azalış ile serada üretim sezonu boyunca zararına devam ettiği görülmüştür. Tuta absoluta'nın serada yüksek yoğunluğa ulaşmasının sebebinin sıcaklık ve nem gibi ekolojik faktörlerin zararlının istekleri doğrultusunda olmasından kaynaklanmış olabileceği düşünülmektedir. Sıcaklık ve nem artışıyla beraber zararlının biyolojisi hızlanmış ve popülasyonu hızlı bir biçimde artmıştır. Çalışmanın yürütüldüğü her iki serada da sıcaklık ve nem bakımından birbirine yakın değerlerin olduğu görülmüştür. Şili'de yapılan bir çalışmada $T$. absoluta'nın gelişmesini $14^{\circ} \mathrm{C}^{\prime}$ de 76.3 günde, $19.7^{\circ} \mathrm{C}^{\prime}$ de 39.8 günde tamamlarken $27.1^{\circ} \mathrm{C}^{\prime}$ de 23.8 günde tamamlamıştır (Barrientos ve ark., 1998). T. absoluta'nın Mayıs sonundan itibaren seralarda popülasyon artışını sıcaklık artışına bağlanmaktadır (Karut ve ark., 2011). Başka bir çalışmada zararlının gelişme süresi artan sıcaklığa bağlı olarak değişmekte olup, $15-29^{\circ} \mathrm{C}$ sıcaklık 
aralığında 78.17 günden 21.39 güne azalmıştır. En düşük, en iyi ve en yüksek sıcaklık istekleri sırasıyla 8.90-12.50, 31.00-31.07 ve 35.90-38.50 aralığında tahmin edilmiştir (Özgökçe ve ark., 2016).

Ferolite tuzaklarındaki ergin birey sayısının, eşey feromon tuzaklarındaki ergin birey sayısından iki kat fazla olduğu tespit edilmiştir. Bunun nedeninin Ferolite tuzağının ışık ve feromon tuzağı kombinasyonu olarak işlev görmesinden dolayı hem dişi hem de erkek bireyleri yakalayabildiği düşünülmektedir (Hassan ve Alzaidi 2010). Bu zararlı ile mücadele eden üreticilerimize seralarda $T$. absoluta'yı kontrol altına almada oldukça etkili olduğundan dolayı Ferolite tuzağı kullanmaları tavsiye edilmektedir.

\section{Ekler}

$\mathrm{Bu}$ çalışma, TÜBITAK (Proje No: 1110347) ve BAP (Proje No: 12201019 ) tarafından desteklenmiş VI. Bitki Koruma Kongresi'nde özet olarak sunulmuş olup, verilerin bir kısmı Zuhal ÖZKAN'ın Yüksek lisans çalışmasından alınmıştır.

\section{Kaynaklar}

Aksoy A., Karaca İ., 2015. Uşak Iilinde Yoğun Domates Yetiştiriciliği Yapılan Alanlarda (Hatipler ve Koyunbeyli) Sera ve Açık Alan Koşullarında Domates Yaprak Galeri Güvesinin Popülasyon Gelişimi. Süleyman Demirel University Journal of Natural and Applied Sciences Volume 19(3): 80-84. Anonim, $2016 a$. http://gapmalatyadanismanlik.com/domat es.html. (Erişim tarihi: 05.04.2016)

Anonim, 2016b. Türkiye Cumhuriyeti Ekonomi Bakanlığı Yaş Sebze ve Meyve Sektör Raporu, Ankara. (Erişim tarihi:05.04.2016)
Anonim, 2016c. Türkiye İstatistik Kurumu (TÜiK)(Erişim tarihi: 05.04.2016)

Anonim, 2016d. Zirai Mücadele Teknik Talimatı: Domates Güvesi Tuta absoluta (Meyrick) (Lepidoptera: Gelechiidae). Tarım ve Köyişleri Bakanlığı Tarımsal Araştırmalar Genel Müdürlüğü, Ankara. (Erişim tarihi: 05.04.2016)

Barrientos Z. R., H. J. Apablaza, S. A. Norero \& P. P. Estay, 1998. Threshold temperature and thermal constant for development of the South American tomato moth, Tuta absoluta (Lep., Gelechiidae). Ciencia e Investigacion Agraria, 133-137.

Bayram Y., Bektaş Ö., Büyük M., Bayram N., , Duman M., Mutlu Ç., 2014a. Güneydoğu Anadolu Bölgesi'nde domates güvesi [(Tuta absoluta Meyrick) (Lepidoptera: Gelechiidae)] ve doğal düşmanlarının sürveyi. Türkiye Biyolojik Mücadele Dergisi,5 (2):99-110

Bayram Y., Bektaş Ö., Büyük M., Bayram N., Duman M., Mutlu Ç., 2014b. Diyarbakır ili domates alanlarında Domates güvesi [Tuta absoluta (Meyrick) (Lepidoptera: Gelechiidae)]'nin popülasyon gelişimi. Bitki Koruma Bülteni, 54(4):343-354

Cáceres, S.,1992. La polilla del tomate en Corrientes. Biología y control. Estación Experimental Agropecuaria Bella Vista, INTA, 19p.

EPPO, 2005. Data sheets on quarantine pests, Tuta absoluta. 2005 EPPO Bulletin 35: 434-435.

Erler F, Can M, Erdoğan M, Ateş AÖ, Pradier T (2010). Domates güvesi, Tuta absoluta Antalya'da.http://www.bioglobal.com.tr/t r.i88.domates-guvesi-tuta-

Estay P., 2000. Polilla del Tomate Tuta absoluta (Meyrick). Impresos CGS Ltd. Available online

at http://www.inia.cl/medios/Decargas/CRI/ Platina/Informativo9.pdf.

Ferrara, F.A.A., E.F Vilela, G. N Jham, A. E Eiras, M. C. Picanço, A.B. Attygalle, A. Stavos, R.T.S. Frighetto and J. Meinwald, 2001. Evaluation of Synthetic Major Component of the Sex Pheromone of Tuta absoluta (Meyrick) (Lepidoptera: Gelechiidae). Journal of Chemical Ecology, 27: 907-917.

Filho, M. M., E. F. Vileda, A. B. Attygalle, J. Meinwald, A. Svatoś and G. N. Jham, 2000. Field trapping of Tomato Moth, Tuta absoluta with Pheromone Traps. Journal of Chemical Ecology, 26: 875-881. 
Hassan M.N. and Alzaidi S.H. 2010. Tuta absoluta A Serious Pest Advancing in the Mediterranean Region, Role of Pheromones in Management Strategies. Int. Pest Manage.,51, 85-87.

Karut K, Kazak C, Döker i, Ulusoy MR 2011. Pest status and prevalence of Tomato moth Tuta absoluta (Meyrick 1917) (Lepidoptera: Gelechiidae) in tomato growing greenhouses of Mersin. Türkiye Entomoloji Dergisi, 35: 339-347.

Kılıç, T.,2010. First record of Tuta absoluta in Turkey. Phytoparasitica, 38:243-244

Mamay M. \& E. Yanık, 2012. Şanlıurfa'da domates alanlarında Domates güvesi [Tuta absoluta (Meyrick) (Lepidoptera: Gelechiidae)'nin ergin popülasyon gelişimi. Türkiye Entomoloji Bülteni, 2 (3): 189-198.

Özgökçe MS, Bayindir A and Karaca I, 2016. Temperature-dependent development of the tomato leaf miner, Tuta absoluta (Meyrick) (Lepidoptera: Gelechiidae) on tomato plant Lycopersicon esculentum Mill. (Solanaceae). Turk Entomol 40:51-59 (2016).

Portakaldalı M., Öztemiz S., Kütük, H., 2013. Adana'da Açı Alan Domates Yetiştiriciliğinde Tuta absoluta (Meyrick) (Lepidoptera: Gelechiidae) ve Doğal Düşmanlarının Popülasyon Takibi. Ege Üniversitesi Ziraat Fakültesi, 27(2),45-54

Ünlü L., 2011. Domates Güvesi, Tuta absoluta (Meyrick)'nın Konya illinde Örtüaltında Yetiştirilen Domateslerdeki Varlığı ve Popülasyon Değişimi. S.Ü. Ziraat Fakültesi Dergisi ,25 (4): 27-29.

Ünlü L., 2012. Potato: A New Host Plant of Tuta absoluta Povolny (Lepidoptera: Gelechiidae) in Turkey. Pakistan Journal of Zoology ,44(4):1183-1184. 